\begin{tabular}{c} 
DURNAI, R ISIIT \\
(Rekayasa Sistem dan Teknologi Informasi) \\
Vol.3 No.3 (2019) $328-335 \quad$ ISSN Media Elektronik: 2580-0760 \\
\hline
\end{tabular}

\title{
Sistem Informasi Monitoring Siswa Menggunakan SMS Gateway
}

\author{
Helvywidya Utari ${ }^{1}$, Yaya Sudarya Triana ${ }^{2}$ \\ ${ }^{1,2}$ Sistem Informasi, Ilmu Komputer, Universitas Mercu Buana \\ ${ }^{1} 41817120015 @$ student.mercubuana.ac.id, ${ }^{2}$ yaya.sudarya@mercubuana.ac.id
}

\begin{abstract}
SMK Telkom Bandung is one of the educational institutions under the Telkom Education Foundation called Telkom Schools. As a school that has a mission to implement information system based on Information and Communication Technologies (ICT) for learning media, SMK Telkom Bandung must have an information system that can process student data related to student absences and grades. The management of absence and grade of student is not efficient because in once assesment process still requires a long time, there are a lot of errors in the sum result and data loss. Where these data are used to measure of the progress of student achievement. Therefore, it is necessary to develop a monitoring system for students who can deliver absent report and student grades to parents quickly through SMS Gateway notifications to help monitor the teaching and learning process in schools. This information system was developed using the SDLC prototype and PIECES analysis approach by integrating Gammu SMS Gateway as a notification feature. In the testing phase using black box testing the results show that the system can documentation absent and grades in a structured manner, be able to convey student attendance report information and grades quickly, teachers can present and evaluate attendance report and reports and grades accurately, as well as with the SMS Gateway notification parents can help monitor the teaching and learning process at school.
\end{abstract}

Keywords: ICT, prototype, monitoring, gammu, sms gateway

\begin{abstract}
Abstrak
SMK Telkom Bandung merupakan salah satu institusi pendidikan yang berada di bawah naungan Yayasan Pendidikan Telkom yang bernama Telkom Schools. Sebagai sekolah yang mempunyai misi menerapkan sistem informasi berbasis Information and Communication Technologies (ICT) untuk media pembelajaran, SMK Telkom Bandung harus memiliki sistem informasi yang dapat mengolah data siswa terkait absen dan nilai siswa. Pengelolaan absen dan nilai siswa dinilai kurang efisien karena dalam sekali proses penilaian masih memerlukan waktu yang lama, sering terjadi kesalahan pada hasil penjumlahan dan sering terjadi kehilangan data dan data tersebut digunakan sebagai alat ukur kemajuan prestasi siswa. Oleh karena itu, perlu dikembangkan suatu sistem monitoring siswa yang dapat menyampaikan informasi laporan absen dan nilai siswa kepada orang tua dengan cepat melalui notifikasi SMS Gateway untuk membantu memonitor proses belajar mengajar di sekolah. Sistem informasi ini dikembangkan dengan pendekatan SDLC prototype dan analisis PIECES dengan mengintegrasikan Gammu SMS Gateway sebagai fitur notifikasi. Pada tahap testing dengan menggunakan black box testing diperoleh hasil bahwa sistem dapat mendokumentasikan data absen dan nilai siswa secara terstruktur, dapat menyampaikan informasi laporan absensi dan nilai siswa dengan cepat, guru dapat menyajikan dan mengevaluasi laporan absensi dan nilai secara akurat, serta dengan fitur notifikasi SMS Gateway orang tua dapat membantu memonitoring proses belajar mengajar di sekolah.
\end{abstract}

Kata kunci: ICT, prototype, monitoring, gammu, sms gateway

(C) 2019 Jurnal RESTI

\section{Pendahuluan}

Sistem informasi memiliki peran yang sangat penting dalam dunia pendidikan di era digital seperti sekarang ini. Seperti halnya SMK Telkom Bandung yang merupakan salah satu institusi pendidikan di bawah naungan Yayasan Pendidikan Telkom yang bernama
Telkom Schools. SMK Telkom Bandung mempunyai misi untuk menerapkan sistem informasi berbasis Information and Communication Technologies (ICT) sebagai media pembelajaran serta informasi dengan 3 Kompetensi Keahlian yang dimiliki, diantaranya

Diterima Redaksi : 27-05-2019 | Selesai Revisi : 12-08-2019 | Diterbitkan Online : 01-12-2019 
Teknik Jaringan Akses Telekomunikasi, Teknik Komputer dan Jaringan dan Multimedia.

Dalam pelaksanaannya, menerapkan sistem informasi berbasis ICT sebagai media pembelajaran serta informasi tidak mudah untuk dilakukan secara menyeluruh. Untuk pengelolaan absensi beserta nilai siswa dinilai kurang efisien. Dalam sekali proses penilaian masih memerlukan waktu yang lama, sering terjadi kesalahan pada hasil penjumlahan dan sering terjadi kehilangan data. Data tersebut digunakan sebagai alat ukur kemajuan prestasi siswa.

Oleh karena itu, SMK Telkom Bandung membutuhkan sistem informasi rapor siswa, agar tidak terjadi kehilangan data absensi dan nilai siswa. Penggunaan sistem informasi pengolahan absensi dan nilai berbasis web dengan gammu sms gateway dapat menjadi alternatif bagi SMK Telkom Bandung dalam menyampaikan laporan absensi dan nilai siswa kepada orang tua.

Sebagaimana Sistem Bring Your Own Device (BYOD) adalah tren yang berkembang di lingkungan perusahaan, di mana karyawan dapat mengakses sistem dari mana saja [1]. Mengadopsi sistem BYOD, sudah selayaknya SMK Telkom Bandung membangun sistem yang dapat diakses dimana saja dan kapan saja dalam rangka membantu memonitor kehadiran dan prestasi siswa.

Untuk mendapatkan implementasi sistem yang lebih baik dari sebelumnya, digunakan metode SDLC prototype dengan analisis PIECES. Analisis PIECES digunakan untuk mengidentifikasi masalah yang ada. Dengan menggunakan analisis PIECES ini akan diperoleh kelebihan dan kekurangan dari sistem yang sedang berjalan, sehingga dapat disimpulkan untuk perbaikan. Analisis PIECES merupakan beberapa proses yang melihat sistem dari Performance, Information/Data, Economic, Control/Security, Efficiency, dan Services [2]. Analisis PIECES kendala dan solusi sistem dijelaskan pada Tabel 1 dan Tabel 2.

Pada Tabel 1 menjelaskan beberapa kendala yang terjadi pada proses bisnis berjalan di SMK Telkom Bandung, sedangkan analisis PIECES solusi pada Tabel 2 menjelaskan solusi dari sistem usulan atas kendala yang terjadi.

Kehandalan (performance) merupakan variabel pertama dari PIECES dimana mempunyai peran penting untuk melihat sejauh mana dan seberapa handalkah suatu sistem informasi dalam berproses untuk menghasilkan tujuan yang diinginkan. Variabel ini dapat digunakan sebagai acuan atau pedoman dalam mengevaluasi sistem dengan memperhatikan 2 komponen, yaitu kemampuan suatu sistem dalam mengerjakan sejumlah perintah/penugasan dalam periode waktu yang telah ditentukan, dengan baik dan tanpa hambatan (errors) dan cepat atau lambatnya kemampuan sistem dalam merespon suatu perintah/program pembatalan ataupun permintaan terhadap suatu transaksi.

Informasi (information) merupakan komoditas krusial bagi pengguna akhir. Evaluasi terhadap kemampuan sistem informasi dalam menghasilkan informasi yang bermanfaat perlu dilakukan untuk menyikapi peluang dan menangani masalah yang muncul. Dalam hal ini meningkatkan kualitas informasi tidak dengan menambah jumlah informasi, karena terlalu banyak informasi malah akan menimbulkan masalah baru.

Analisis Ekonomi (economic) merupakan motivasi paling umum bagi suatu proyek. Pijakan bagi kebanyakan manajer adalah biaya atau rupiah. Persoalan ekonomis dan peluang berkaitan dengan masalah biaya.

Analisis Keamanan (security) merupakan tugas-tugas bisnis perlu dimonitor dan dibetulkan jika ditemukan kinerja yang di bawah standar. Kontrol dipasang untuk meningkatkan kinerja sistem, mencegah, atau mendeteksi kesalahan sistem, menjamin keamanan data, dan persyaratan.

Analisis Efisiensi (efficiency) menyangkut bagaimana menghasilkan output sebanyak-banyaknya dengan input yang sekecil mungkin. Berikut adalah suatu indikasi bahwa suatu sistem dapat dikatakan tidak efisien: banyak waktu yang terbuang pada aktivitas sumber daya manusia, mesin, atau komputer, data dimasukkan atau disalin secara berlebihan, data diproses secara berlebihan, informasi dihasilkan secara berlebihan, usaha yang dibutuhkan untuk tugastugas terlalu berlebihan, dan material yang dibutuhkan untuk tugas-tugas terlalu berlebihan.

Analisis Layanan (services) merupakan keriteria penilaian dimana kualitas suatu sistem bisa dikatakan buruk: sistem menghasilkan produk yang tidak akurat, sistem menghasilkan produk yang tidak konsisten, sistem menghasilkan produk yang tidak dipercaya, sistem tidak mudah dipelajari, sistem tidak mudah digunakan, sistem canggung untuk digunakan, dan sistem tidak fleksibel.

Dari hasil penelusuran di berbagai publikasi terutama jurnal dapat diketahui beberapa penelitian tentang monitoring siswa sudah dilaporkan oleh Arniyanto Putri pada penelitian yang dilakukan di SMP Negeri 1 Yogyakarta mengenai sistem informasi pengolahan nilai rapor pada siswa SMP Negeri 1 Yogyakarta berbasis web, disimpulkan bahwa aplikasi dibangun untuk mempermudah siswa dan wali murid untuk melihat data nilai tanpa batasan waktu dan dengan adanya sistem informasi pengolahan nilai rapor berbasis website maka keseluruhan proses manual dalam melakukan input data dan nilai menjadi lebih efisien waktu dan biaya. Penelitian ini menggunakan analisis PIECES dan perancangannya menggunakan 
DFD. Metode pengujian yang digunakan adalah Black Box Testing [3].

Pada penelitian yang dilakukan di SMA Negeri 1 Krembung mengenai sistem informasi rapor online SMA Negeri 1 Krembung. Secara garis besar sistem informasi rapor online sangat membantu dalam proses pengelolaan data guru, data kelas, mata pelajaran dan laporan nilai rapor siswa. Sistem ini memberikan kemudahan bagi guru mata pelajaran dan wali kelas dalam mengelola nilai maupun memberikan informasi kepada orang tua siswa secara cepat tanpa membutuhkan waktu lama [4].

Pada penelitian yang berjudul "Sistem Manajemen Informasi Siswa Berbasis Web" disimpulkan bahwa sistem tersebut terbukti dapat membantu dalam mengotomatisasi sistem yang sedang berjalan saat ini. Sistem mampu memberikan informasi yang akurat karena data tersimpan dengan rapi dan dapat diakses kapan saja. Informasi yang dibutuhkan juga dapat diperoleh secara cepat [5].

Pada penelitian yang berjudul "Adaptasi Sistem Berbasis Web Arsitektur dalam Pengembangan Online Sistem Kehadiran" disimpulkan bahwa sistem online merupakan kebutuhan akan proses pencatatan dan pelaporan kehadiran siswa [6].

\section{Metode Penelitian}

Monitoring merupakan pengawasan yang dapat dijelaskan sebagai tingkat kesadaran tentang apa yang harus digali lebih dalam dan pengukuran yang dilakukan untuk menunjukkan sejauh mana tujuan tersebut telah tercapai [7].

UML adalah sebuah bahasa yang telah menjadi standar dalam industri untuk visualisasi, merancang dan mendokumentasikan sistem piranti lunak. UML menawarkan sebuah standar untuk merancang model sebuah sistem [8].

Blackbox Testing merupakan pengujian sistem yang berfokus pada pengujian fungsionalitas perangkat lunak yang dibangun. Tester juga dapat menentukan kondisi dan antarmuka output dari perangkat lunak tidak cukup benar. Kecenderungan dalam menggunakan pengujian Blackbox adalah mengamati fungsi yang salah atau tidak ada pada aplikasi, kesalahan pada antarmuka, kesalahan dalam struktur data dan akses database, kesalahan dalam kinerja dan kesalahan yang terjadi selama inisialisasi aplikasi dan penghentian [9].

\subsection{Metodologi}

Dalam penyusunan penelitian ini, diperlukan adanya alur kerja dan tahapan yang jelas. Alur kerja disini merupakan langkah-langkah yang akan dilakukan dalam penyelesaian masalah yang ada. Langkahlangkah yang dilakukan diantaranya, pengumpuan data, studi literatur dan observasi, analisis masalah (PIECES), usulan rancangan sistem, pembuatan sistem, testing dan implementasi dan penulisan laporan. Dalam penelitian ini metode pengembangan sistem yang digunakan adalah System Development Life Cycle (SDLC) dengan model pengembangan Prototype Model. Prototype Model ini terdiri dari beberapa tahap pengembangan yaitu Communication (komunikasi), Quick Plan (rancangan cepat), Construction of Prototype (membangun prototype) dan Deployment Delivery and Feedback (penyerahan prototype dan umpan balik).

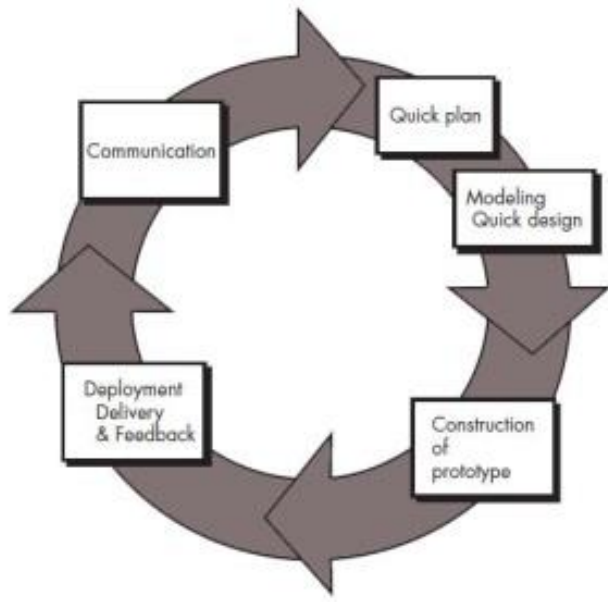

Gambar 1. Paradigma Prototype [10]

Tahap komunikasi (Communication) pada metode Prototype merupakan komunikasi antara tim pengembang perangkat lunak dengan pelanggan. Tahap rancangan cepat (Quick Plan) merupakan kegiatan merancangan prototype yang telah mewakili sistem yang akan dibangun. Pada tahap ini dilakukan desain use case diagram sistem yang ditunjukkan pada Gambar 2 dan class diagram yang ditunjukkan pada Gambar 3. Use Case Diagram pada Gambar 2 menjelaskan bahwa terdapat 5 actor yang terlibat dalam pembuatan sistem. Wali Kelas dan Guru Mata Pelajaran dapat mengolah absensi dan nilai. Admin dapat mengolah data master, mengolah nilai, absensi dan mengatur notifikasi. Siswa dapat melihat informasi terkait nilai dan absensi. Dan yang terakhir orang tua menerima sms notifikasi terkait absensi dan nilai siswa. Untuk Class Diagram sendiri menggambarkan relasi table yang terlibat. Tahap membangun prototype (Construction of Prototype) merupakan proses mewujudkan rancangan prototype atau desain menjadi kenyataan. Tahap penyerahan prototype dan umpan balik (Deployment Delivery and Feedback) merupakan proses penyerahan sistem kepada para stakeholder dan kemudian mereka akan melakukan evaluasi-evaluasi tertentu terhadap prototype yang telah dibuat sebelumnya, kemudian akhirnya akan memberikan umpan balik yang akan digunakan untuk memperhalus spesifikasi kebutuhan. Iterasi akan terjadi saat protoype diperbaiki untuk

Jurnal RESTI (Rekayasa Sistem dan Teknologi Informasi) Vol . 3 No. 3 (2019) 328 - 335 
memenuhi kebutuhan dari para stakeholder, sementara pada saat yang sama memungkinkan kita untuk lebih memahami kebutuhan apa yang akan dikerjakan pada iterasi selanjutnya. Tahapan model pengembangan Prototype ditunjukkan pada Gambar 1.

\subsection{Analisis PIECES}

Berikut ini adalah pemaparan dari analisis PIECES (Peformance, Information, Economics, Control, Efficiency, Service) untuk mengetahui manfaat dari sistem yang diusulkan, di antaranya dapat dilihat pada Tabel 1.

Tabel 1.Tabel Analisis PIECES Kendala

\begin{tabular}{|c|c|}
\hline PIECES & Kendala \\
\hline Performance & $\begin{array}{l}\text { Untuk menyelesaikan } 1 \text { rapor tergolong lama. } \\
\text { Karena wali kelas harus melihat ulang nilai dan } \\
\text { wali kelas juga harus mendapatkan daftar nilai } \\
\text { akhir dari guru mata pelajaran yang } \\
\text { bersangkutan. }\end{array}$ \\
\hline Information & $\begin{array}{l}\text { Pada sistem berjalan saat ini, sering terjadi } \\
\text { kesalahan pada hasil penjumlahan dan sering } \\
\text { terjadi kehilangan data. }\end{array}$ \\
\hline Economic & $\begin{array}{l}\text { Biaya yang dikeluarkan cukup banyak. } \\
\text { Contohnya: pembelian buku nilai untuk } \\
\text { pencatatan data nilai dan pembelian bolpoin } \\
\text { untuk alat tulis. }\end{array}$ \\
\hline Control & $\begin{array}{l}\text { Pada sistem berjalan saat ini, sering terjadi } \\
\text { kerusakan pada daftar nilai akhir yang } \\
\text { disebabkan kelalaian manusia, seperti hilang atau } \\
\text { terselip. Maka apabila data hilang, akan } \\
\text { membutuhkan waktu yang lama lagi untuk } \\
\text { memproses semuanya. }\end{array}$ \\
\hline Efficiency & $\begin{array}{l}\text { Banyaknya waktu yang terbuang jika wali kelas } \\
\text { harus mengurus rapor siswa yang diampu dan } \\
\text { juga bertanggung jawab dengan nilai akhir mata } \\
\text { pelajaran yang diampu di kelas lain. Dengan } \\
\text { proses yang berjalan seperti itu membuat tidak } \\
\text { efisien dalam pembuatan rapor. }\end{array}$ \\
\hline Service & $\begin{array}{l}\text { Orang tua harus datang ke sekolah untuk } \\
\text { mengetahui data absensi dan nilai siswa. Untuk } \\
\text { studi kasus pada SMK Telkom Bandung yang } \\
\text { memiliki siswa yang tersebar di seluruh } \\
\text { Indonesia, orang tua harus mengalokasikan } \\
\text { tenaga, waktu dan biaya lebih untuk } \\
\text { mendapatkan informasi tersebut. }\end{array}$ \\
\hline
\end{tabular}

Tabel 2.Tabel Analisis PIECES Solusi

\begin{tabular}{ll}
\hline PIECES & Solusi \\
\hline Performance & $\begin{array}{l}\text { Dibuatkan Web Rapor Siswa, dalam menu wali } \\
\text { kelas untuk men-generate laporan siswa dalam } \\
\text { bentuk file pdf. }\end{array}$ \\
Information & $\begin{array}{l}\text { Dibuatkan Web Rapor Siswa, dengan fitur } \\
\text { tambah, ubah dan hapus data untuk menghindari }\end{array}$ \\
& kehilangan data dan input data. \\
Economic & Adanya penghematan dari sisi biaya (costs) \\
& dalam institusi, berarti penggunaan sistem sudah \\
& tepat untuk diaplikasikan dalam kegiatan tata \\
& kelola. \\
& Dibuatkan Web Rapor Siswa dengan user yang \\
memiliki hak akses password dan username yang \\
berbeda, sehingga setiap user memiliki kontrol \\
pada data yang di-input. Sehingga kelalaian yang \\
disebabkan oleh manusia seperti kehilangan data \\
akan bisa di minimalisir oleh sistem. \\
Dibuatkan Web Rapor Siswa untuk mendukung \\
wali kelas dalam menyelesaikan rapor siswa
\end{tabular}

menjadi relatif singkat dan hasil yang diperoleh akurat.

Service Dibuatkan Web Rapor Siswa untuk memberikan kemudahan bagi orang tua dalam mendapatkan informasi terkait absensi dan nilai siswa.

\section{Hasil dan Pembahasan}

\subsection{Perancangan Proses}

Diagram Use Case memberikan gambaran seluruh elemen sistem. Terdapat lima aktor yang terlibat dalam pembuatan sistem sesuai dengan analisis proses berjalan, yaitu: Admin, memiliki hak akses dan tugas untuk melakukan operasi pengelolaan data master dan pengolahan notifikasi atau pengingat. Wali kelas, seorang guru yang diberikan tanggung jawab oleh Kepala Sekolah untuk membina murid dalam satu kelas. Bertugas untuk mengolah nilai dan absensi dari kelas yang di bina. Guru Mata Pelajaran, merupakan guru pengampu setiap mata pelajaran. Bertugas untuk mengolah nilai dan absensi siswa. Orang Tua/Wali Murid, merupakan seseorang yang menjamin dan bertanggung jawab terhadap seorang anak di sekolahnya, seperti ibu, bapak, saudara. Dan Siswa, merupakan individu yang secara resmi terdaftar untuk mengikuti pelajaran di dalam dunia pendidikan. Untuk mengetahui detail sistem usulan yang diperoleh dari analisis sistem berjalan, dapat dilihat pada Gambar 2 .



Gambar 2. Use Case Diagram

Use case diagram adalah gambaran dari beberapa atau seluruh aktor dan use case dengan tujuan mengenali

Jurnal RESTI (Rekayasa Sistem dan Teknologi Informasi) Vol . 3 No. 3 (2019) 328 - 335 
interaksi mereka dalam suatu sistem. Use case diagram menggambarkan fungsionalitas yang diharapkan dari sebuah sistem, yang ditentukan adalah "apa" yang diperbuat sistem, dan bukan "bagaimana". Sebuah use case merepresentasikan sebuah interkasi antara aktor dengan sistem [8].

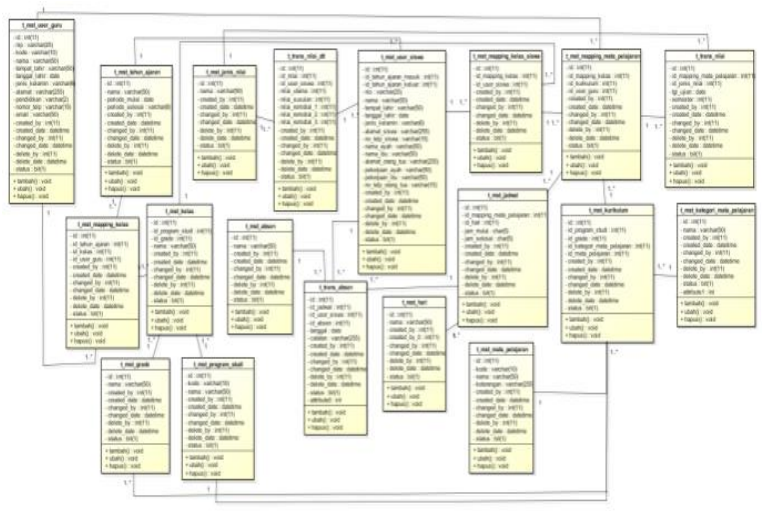

Gambar 3. Diagram Class

Definisi dari masing-masing Use Case: Login merupakan proses pengecekan untuk mengakses aplikasi dengan memasukkan username dan password dari user tersebut yang sudah terdaftar dalam database. Mengolah absensi siswa merupakan proses yang meliputi dua buah proses yaitu menambah dan mengubah data absensi siswa. Mengolah nilai siswa merupakan proses yang meliputi dua buah proses yaitu menambah dan mengubah data nilai siswa. Melihat data nilai merupakan proses select data dari basis data untuk melihat data nilai siswa. Melihat data absen merupakan proses select data dari basis data untuk melihat data absensi siswa. Mengolah data master merupakan proses generalisasi yang meliputi empat buah proses yaitu melihat, menambah, mengubah dan menghapus data master.

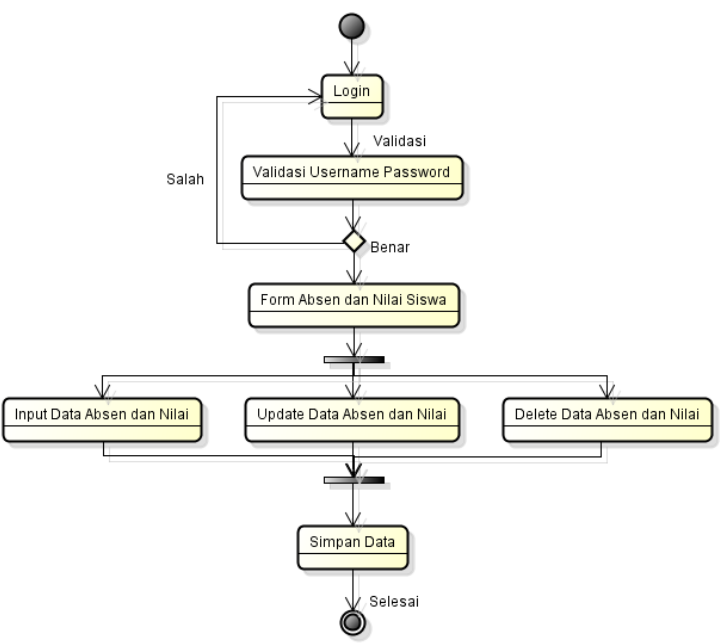

Gambar 4. State Chart Diagram

\subsection{Diagram Class}

Diagram Class digunakan untuk menggambarkan struktur sistem dari segi pendefinisian kelas-kelas yang yang akan dibuat untuk membangun system [6].

\subsection{State Chart Diagram}

State Chart Diagram digunakan untuk memodelkan tingkah laku objek khusus yang dinamis.[8]

\subsection{Sequence Diagram}

Sequence diagram menjelaskan interaksi objek yang disusun berdasarkan urutan waktu, tahap demi tahap yang harus dilakukan untuk menghasilkan sesuatu sesuai dengan use case [8].

Berikut gambaran untuk setiap sequence diagram:

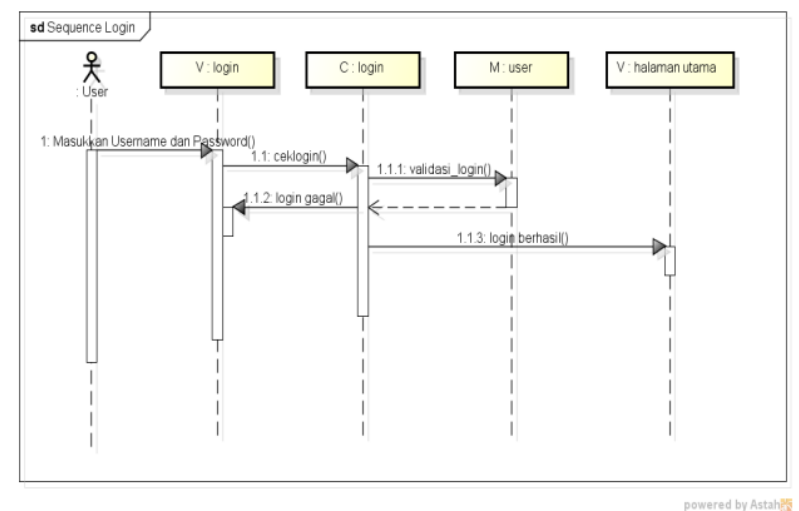

Gambar 0. Sequence Login

Berikut adalah penjelasan Sequence Diagram Login: user membuka aplikasi, halaman login akan menampilkan form input email dan password, user memasukan data email dan password, data inputan user dikirim dari halaman Login ke sistem dan sistem akan meneruskan pengiriman data ke database, database akan memvalidasi data email dan password user, jika data email dan password tidak valid, maka sistem akan mengirimkan notifikasi bahwa data yang diinput salah, jika data email dan password valid, maka sistem akan menampilkan halaman utama.

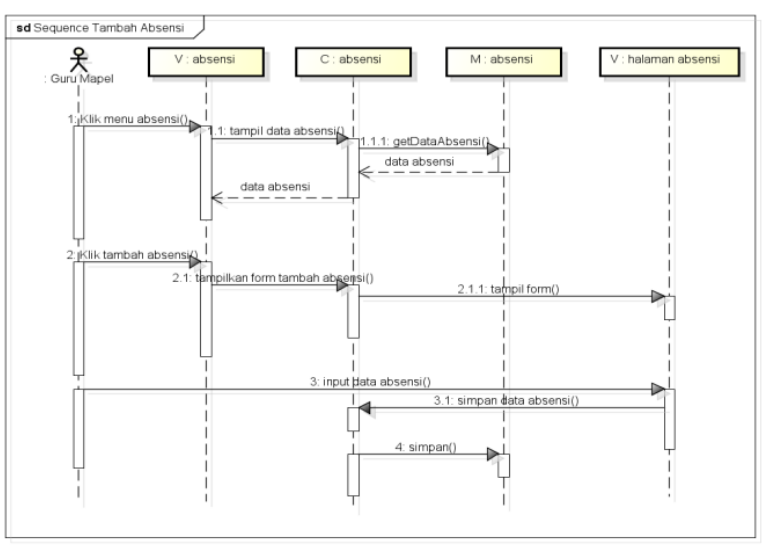

Gambar 6. Sequence Menambah Absensi

Jurnal RESTI (Rekayasa Sistem dan Teknologi Informasi) Vol . 3 No. 3 (2019) 328 - 335 
Berikut adalah penjelasan Sequence Diagram Menambah Absensi: guru mata pelajaran membuka halaman tambah absensi, halaman tambah absensi akan menampilkan form tambah absensi, guru mata pelajaran menambah data absensi, klik tombol simpan, data absensi akan tersimpan ke dalam database.

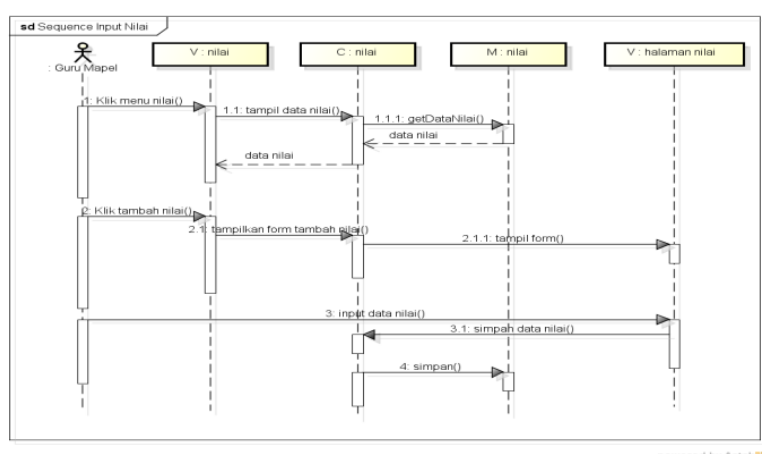

Gambar 7. Sequence Menambah Nilai

Berikut adalah penjelasan Sequence Diagram Menambah Nilai: guru mata pelajaran membuka halaman tambah nilai, halaman tambah nilai akan menampilkan form tambah nilai, guru mata pelajaran menambah data nilai, klik tombol simpan, data nilai akan tersimpan ke dalam database

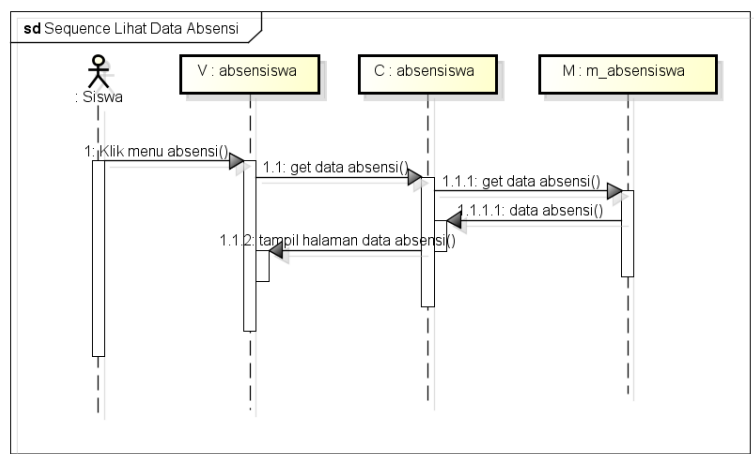

Gambar 8. Sequence Melihat Data Absens

Berikut adalah penjelasan Sequence Diagram Melihat Data Absensi: siswa membuka halaman absensi, halaman absensi akan menampilkan data absensi

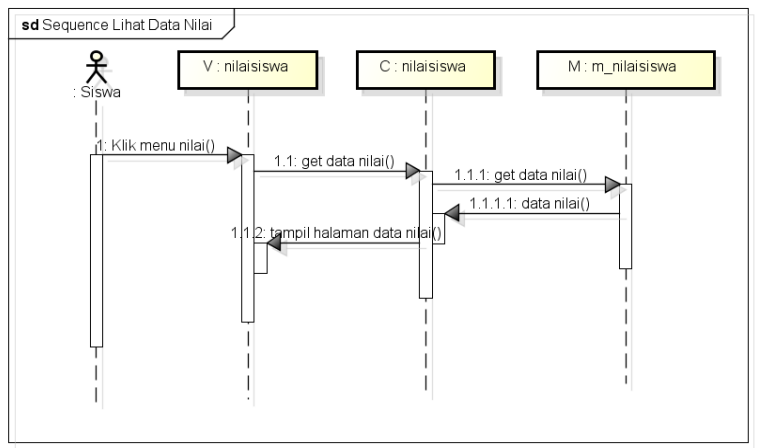

Gambar 9. Sequence Melihat Data Nilai
Berikut adalah penjelasan Sequence Diagram Melihat Data Nilai: siswa membuka halaman nilai, halaman nilai akan menampilkan data nilai



Gambar 10. Sequence Menambah Data Master

Berikut adalah penjelasan Sequence Diagram Menambah Data Master: admin memilih submenu data master yang akan ditambah, halaman submenu yang dipilih akan menampilkan keseluruhan data master, pilih "New" untuk menambahkan data master, klik tombol simpan, data master akan tersimpan ke dalam database

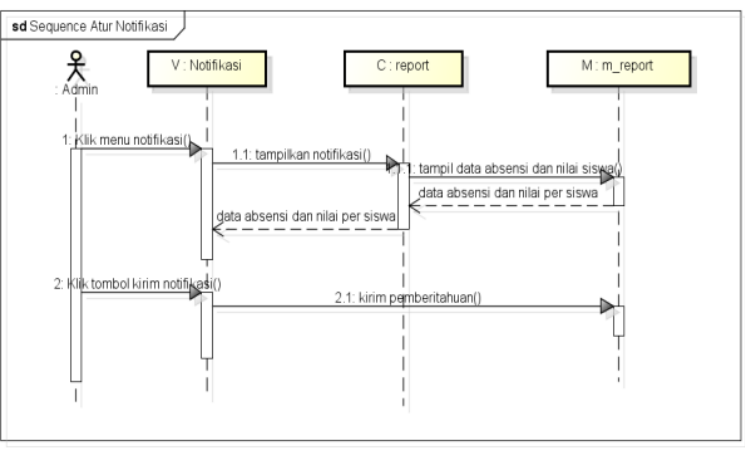

Gambar 11. Sequence Mengatur Notifikasi

Berikut adalah penjelasan Sequence Diagram Mengatur Notifikasi: admin memilih menu Transaksi $>$ Nilai/Absensi > Posting, halaman akan menampilkan data nilai/data absensi, pilih "Kirim" untuk mengirimkan data nilai/absensi kepada orang tua

\subsection{Implementasi Sistem}



Jurnal RESTI (Rekayasa Sistem dan Teknologi Informasi) Vol . 3 No. 3 (2019) 328 - 335 
Gambar 12 merupakan halaman transaksi kelola nilai. Pada halaman ini guru dapat melakukan tambah, ubah dan hapus nilai siswa.

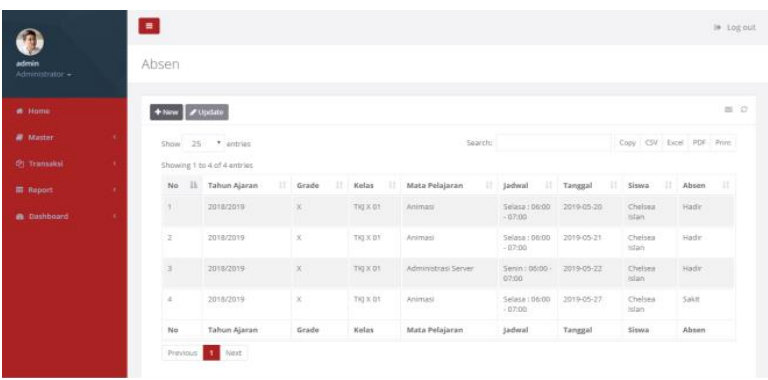

Gambar 14. Antar Muka Transaksi Kelola Absen

Gambar 14 merupakan halaman transaksi kelola absen. Pada halaman ini guru dapat melakukan tambah, ubah dan hapus absen siswa.
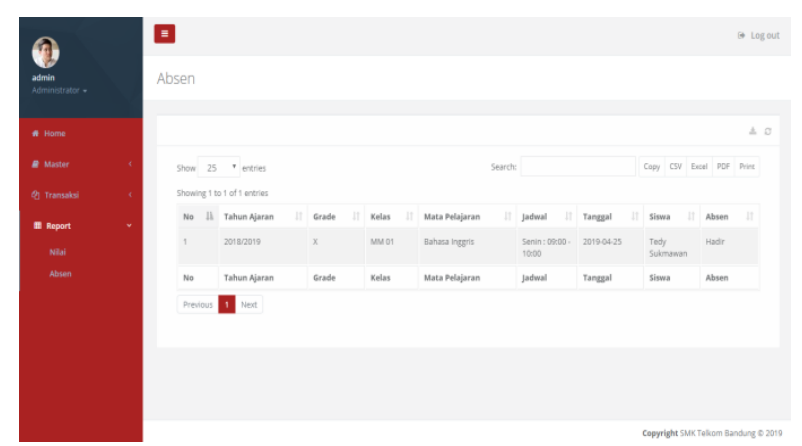

Gambar 13. Antar Muka Report Absen

Gambar 13 merupakan halaman report absen yang menampilkan informasi detail absen siswa. Pada halaman ini guru dapat melakukan tambah, ubah dan hapus absen siswa, serta guru dapat men-download file report absen siswa.
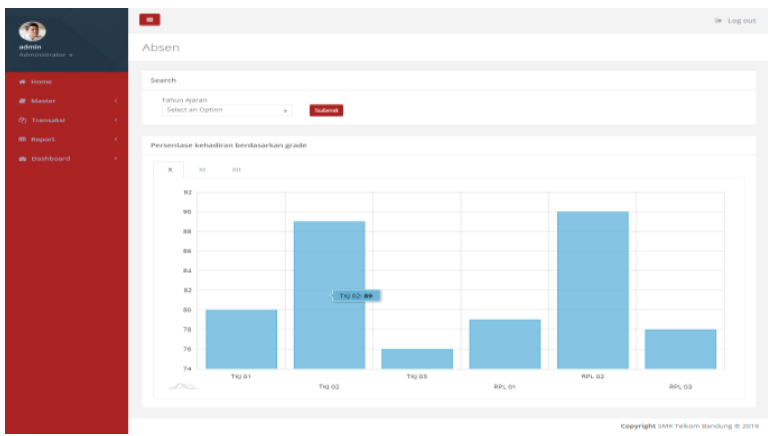

Gambar 17. Antar Muka Dashboard Absen

Gambar 17 merupakan halaman dashboard absen. Menampilkan informasi dalam bentuk grafik yang menyajikan informasi presentase kehadiran berdasarkan grade.

Menampilkan informasi kehadiran siswa setiap harinya dan nilai akhir yang diperoleh siswa pada setiap mata pelajaran
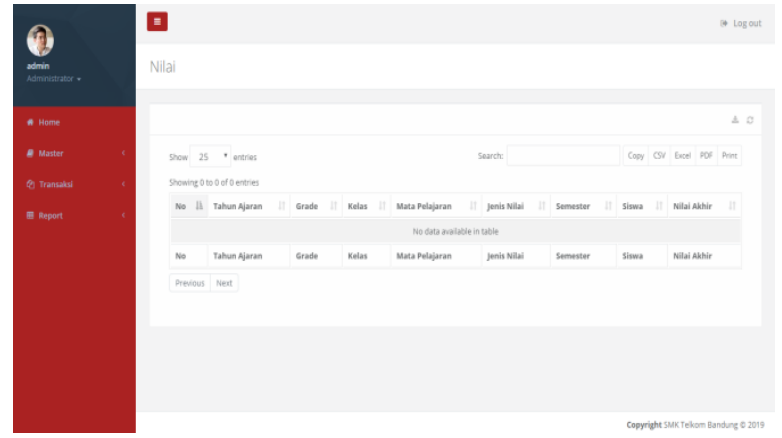

Gambar 15. Antar Muka Report Nilai

Gambar 15 merupakan halaman report nilai yang menampilkan informasi detail nilai siswa. Pada halaman ini guru dapat melakukan tambah, ubah dan hapus nilai siswa, serta guru dapat men-download file report nilai siswa.
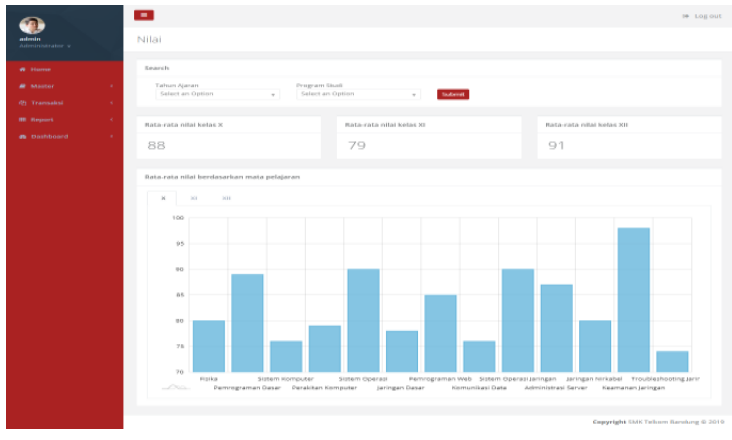

Gambar 16. Antar Muka Dashboard Nilai

Gambar 16 merupakan halaman dashboard nilai. Menampilkan informasi dalam bentuk grafik dengan menyajikan informasi rata-rata nilai berdasarkan mata pelajaran pada setiap grade. Nilai akhir yang diperoleh harus diatas KKM yang sudah ditentukan oleh pihak sekolah, yakni 70 .

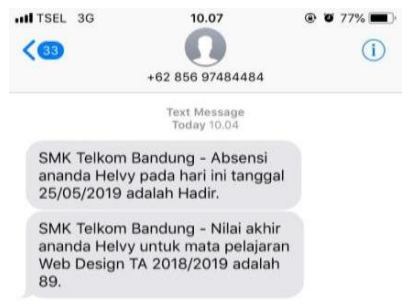

(1) $A$ )

Gambar 18. Halaman Implementasi SMS Gateway 


\section{Kesimpulan}

Berdasarkan analisis, perancangan dan implementasi terhadap sistem yang telah dibuat. Diperoleh kesimpulan yaitu, SMK Telkom Bandung dapat menyampaikan informasi laporan absensi dan nilai akhir siswa kepada orang tua dengan cepat, guru dapat menyajikan dan mengevaluasi laporan absensi dan nilai dengan status yang lebih rapi, lengkap dan detail, serta orang tua dapat menerima notifikasi melalui SMS Gateway berupa informasi absensi dan nilai untuk membantu me-monitor proses belajar mengajar di sekolah. Nilai akhir yang dikirim merupakan nilai olahan yang sudah mencapai KKM, yakni 70 .

\section{Daftar Rujukan}

[1] Retnowardhani, Astari., Diputra, Raziv Herman., \& Triana, Yaya Sudarya. 2019. Security risk analysis of bring your own device ( BYOD ) system in manufacturing company at Tangerang. TELKOMNIKA, Vol.17, No.2, pp.753-762.

[2] Susena, Edy., Utami, Ema., \& Sunyoto, Andi. 2015 Perencanaan Strategis Sistem Informasi Smart Campus Untuk Meningkatkan Pelayanan di Politeknik Indonusa Surakarta.
Jurnal Sainstech Politeknik Indonusa Surakarta, Vol. 1, No. 3.

[3] Arniyanto Putri, Nenzy Ahlung., \& Hartanto, Anggit Dwi. 2013. Sistem Informasi Pengolahan Nilai Raport Pada Siswa SMP Negeri 1 YOGYAKARTA Berbasis Web. Jurnal Ilmiah DASI Vol. 14 No. 04 Desember, hlm 38 - 43.

[4] Budiyarto, Nyuda Resio., \& Rochmawati, Naim. 2016. SISTEM INFORMASI RAPORT ONLINE SMA NEGERI 1 KREMBUNG. Jurnal Manajemen Informatika. Volume 6 Nomor 1 Tahun 2016, 108-116.

[5] Bharamagoudar, S.R., Geeta, R.B., \& Totad, S.G. 2013. Web Based Student Information Management System. International Journal of Advanced Research in Computer and Communication Engineering Vol. 2, Issue 6, pp. 2342-2348.

[6] Othman, Mahfudzah., Ismail, Siti Nurbaya., \& Noradzan, Haslinda. 2012. An adaptation of the web-based system architecture in the development of the online attendance system. IEEE Conference on Open Systems, ICOS.

[7] Mesterjon. 2016. Street Light Monitoring Application Based On SMS Gateway. International Journal of Scientific and Research Publications, Volume 6, Issue 11, pp. 536-539.

[8] Sugiarti. 2013. Analisis \& Perancangan UML (Unified Modeling Language), Graha Ilmu.

[9] Noviyantono, Endyk., Aidil, 2012. Integration System Of Web Based And SMS Gateway For Information System Of Tracer Study.

[10] Pressman, Roger S, 2015. Rekayasa Perangkat Lunak. Buku Satu Pendekatan praktisi (Edisi 7). Yogyakarta: ANDI. 